The fourth treatise is an extract from various books of Galen on drugs, treatment, aetiology and symptomatology.

The fifth treatise is a theoretical exposition of hypothetical diseases of the membranes and humours of the eye.

The sixth treatise is particularly interesting because it has no model in Galen's existing works. It probably follows his lost treatise "The Diagnosis of Eye-diseases." It begins with the symptoms of conjunctival diseases. An entirely new fact here comes to light that pannus was not observed for the first time by the Arabs but was known to the Greeks under the name of kirsophthalmia.

The seventh and eighth treatises deal with simple remedies.

The ninth treatise describes the operation of couching a cataract.

The tenth treatise contains a number of prescriptions for ophthalmic remedies. It has the following preface by Hunain :"During more than thirty years I had composed different treatises concerning the eye in which I pursued divergent aims about which I was questioned by several people one after another. Then one of my friends (his nephew Hubaish), collected those treatises and asked me to give them titles after having united them all in one volume in a convenient manner and so I did this."

Hunain ends his volume with the satisfying sentence :- "This is a book containing all the knowledge necessary for those who wish to treat the diseases occurring in the eye in a reasonable manner."

It is difficult to compute the days and nights of labour which Meverhof must have spent in preparing this book for publication, and as difficult to estimate the heavy private expenditure which it must have involved. However, most of us can dimly appreciate the scholarship required for work of this kind, and congratulate Ophthalmology on having so erudite a disciple.

\title{
MARGINAL DEGENERATION OF THE CORNEA
}

BY

\section{J. H. DOgGaRT}

LONDON

MARGINAL degeneration of the cornea is a rare, bilateral condition, twice as common in men as in women, with opacity and vascularisation of the peripheral zone of the cornea as its earliest signs. The epithelium remains intact, but there follows a progressive thinning of the cornea at the expense of Bowman's membrane and the anterior layers of the substantia propria, so that a gutter is formed. 
As the stroma slowly continues to melt away, the gutter deepens until at last this portion of the cornea is rendered unable to sustain the normal intra-ocular pressure, and begins to bulge. This final stage of ectasia is in many cases delayed until 10-20 years after the onset of degeneration. The upper half of the periphery is more commonly affected than the lower. If the whole circumference is involved, the process is usually further advanced above than below. An inferior ectasia is exceedingly rare. The process of attenuation steadily advances in its original situation, and often, but by no means always, extends further round the circumference. It is sometimes possible to detect, in one and the same cornea, a normal zone, a furrow, and an ectasia. Multiple localised, vesicular ectasiae may occur at intervals along the course of a furrow. Between the limbus and the peripheral edge of the opacity, there intervenes a strip of apparently clear cornea, but the slit-lamp reveals a continuation of small greyish dots in the deeper layers of the stroma right up to the limbus (cf. arcus senilis). Until the characteristic furrow appears, marginal degeneration can simulate arcus senilis, but a more detailed examination reveals the presence of fine vessels encroaching on the opaque area if the case is really one of marginal degeneration. The two conditions are quite distinct, because: (1) Approximately one-third of some 80 cases described with more or less detail in the literature were under the age of forty. In a few instances, the patient has been under twenty years old. (2) In several instances even of elderly patients suffering from typical marginal degeneration, the absence of an arcus has been specifically mentioned. (3) Furrows have been seen separate from, and bearing either a peripheral or a central relation to an arcus. On its peripheral side the furrow shelves gradually, but its central edge is steep. This central edge becomes increasingly accentuated, and stands out during the ectatic stage as a wavy white line, of a chalky appearance. The radial vessels and their loops rarely transgress the white line by more than a millimetre, and in most cases are sharply arrested thereby. Occasionally a furrow is limited both peripherally and centrally by white lines, whose extremities fuse at the ends of the crescent. When the stage of ectasia is reached, the affected area of the cornea inevitably regains some of its transparency because of the exaggerated thinning.

One important effect of marginal degeneration is a flattening of the cornea in that meridian which passes through the middle of the furrow or ectasia. Since the upper half of the periphery is the favourite site for these formations, the vertical meridian suffers a reduction in its curvature. Hence follows an astigmatism against the rule, amounting frequently to more than $10 \mathrm{D}$., and in a few cases to as much as $20 \mathrm{D}$. Moderately good visual acuity may be obtained by trial of a high minus cylinder with its axis vertical, but in most 
cases the much less adyanced degree of the deformity in the patient's fellow eye prevents him from wearing the appropriate glass. On the other hand, it may be impossible to improve the vision by test lenses, more particularly in those eyes where the furrow is seen to extend round most of the circumference. In such cases the central portion of the cornea may bulge diffusely as a result of its impaired nutrition. This complication produces an irregular astigmatism, not amenable to improvement by test-lenses, and clinically bears a rough resemblance to the picture of keratoconus. Sometimes in advanced cases there are small, ill-defined areas of opacity scattered irregularly in the substantia propria of the central portion of the cornea, remote from the limiting white line. The sensibility of the cornea to touch is usually unimpaired in the unaffected areas, and in an early opacity; diminished or absent on the floor of a furrow; completely absent over the ectasia. Intra-ocular tension is normal. In a large proportion of cases, pterygia or pseudo-pterygia, which sometimes undergo spontaneous resolution, have been described.

The cardinal symptom is a slow failure of vision in one eye, followed after a number of years by the onset of a similar disability in the other. Symptoms in the second eye may be delayed as long as 25 years. Even so, the proportion of unilateral cases in the literature is small. Therefore it would seem reasonable to foretell, concerning any individual unilateral case, that his other eye will in time become involved if he lives long enough. In one-third of the cases at least, there is a history of intermittent conjunctivitis or vague irritability and discomfort of the eyes, preceding the visual failure by an interval, maybe of years. The possible significance of these attacks will be discussed later. Since the disease progresses slowly, and is for a long time limited to one eye, many patients remain for years in ignorance of any disability. Their ignorance may be suddenly dispersed by the dramatic event of a ruptured globe. It is only to be expected that an ectatic area, whose thickness is about one-quarter the thickness of the normal cornea, stands in danger of perforation from slight trauma. Several examples of this mishap are on record. In Uhthoff's patient, a gentle poke with a finger sufficed to rupture the cornea and extrude the lens. Twelve years later, this unfortunate man suffered the same disaster in the other eye as a result of a similar blow. An ectasia sometimes gives way after a fall on the ground, without there having been any direct blow on the eye. Schutz reports the case of a boy of 18 who woke up one morning to feel a pain in the left eye. There was a perforation of the cornea with prolapse of iris. Another curious feature of this unique case was the behaviour of the right eye, which also became painful two days later. It was found to show a typical upper peripheral vascularised ectasia limited by a white line, and appeared to be threatened with the same fate 
as the other eye. Under treatment by eserine and a pressure bandage, this right ectasia subsided ten days later.

Thinning of the corneal periphery naturally calls for extreme care in the event of an operation becoming necessary for the extraction of a senile cataract. Axenfeld and Gifford each report a successful extraction, although Axenfeld's case occasioned some temporary anxiety by developing ring infiltration. These operators both used a conjunctival flap to fortify the cornea in the neighbourhood of their section. Is it possible that the pseudo-pterygia repeatedly observed in marginal degeneration represent an attempt on the part of the tissues to guard against the risk of rupture by drawing a hood of conjunctiva over the danger zone?

Operations to arrest the disease have been undertaken by several surgeons. Terrien treated a patient 30 years ago by repeated cauterisation of the ectatic area, with the object of reducing the astigmatism by cicatricial contraction (cf. scarring after cataract extraction, with lessening in the amount of astigmatism against the rule). Four months after the beginning of this treatment, Terrien was able to report that the amount of astigmatism in the worse eye was reduced from $11 \mathrm{D}$. to $1 \mathrm{D}$. Adamantiadis adopted Terrien's plan with partial success. J. H. Fisher obtained useful corrected vision, and converted an astigmatism against the rule to an astigmatism with the rule by excising a lunula of ectatic cornea, whose pathological appearances were subsequently described by Coats. In most cases of this disease, active treatment is not indicated. Relief is afforded by the prescription of glasses to correct the astigmatism, if the discrepancy between the refraction of the two eyes is not too great.

Pathological findings have been described in detail by Fuchs, Seefelder, Rupprecht, and Coats. They confirm the clinical observation of corneal thinning with a sharp central boundary. The epithelium is in situ, though the form of its cells, especially of the basal ones, may be modified. Bowman's membrane and the anterior layers of the substantia propria are usually described as being absent, but Fuchs in his second paper regards them as merely thinned and teased out into slender fibrils. Deep to the epithelium is a layer of vascular granulation tissue showing little or no infiltration with inflammatory cells. Seefelder observed numerous fat granules in the stroma of the floor of the furrow, and between some of the normal lamellae lying central to the limiting line. According to most of the observations, Descemet's membrane was practically normal, but Coats found it laminated and thickened fourfold. To explain this atypical thickening, Coats postulated a slow process allowing time for resistance. Fisher emphasised the comparative youth of the patient (aged 41 years) as likely to be attended by a high grade of proliferative activity in Descemet's endothelium. 
The cause of this disease is unknown. Bacteriological investigations have produced negative or inconstant results. Three cases have been reported after trachoma; one other case in association with iridocyclitis; one with glaucoma; one with a history of malnutrition from war rations. Two cases of Cattaneo showed hypercholesterinaemia. Most or all of these facts might well be coincidental. There has been disagreement as to whether the disease is essentially a degenerative or an inflammatory process. The slow progress and the bilaterality suggest degeneration, but a low-grade inflammation has been adduced as the reason for the preceding symptoms of irritability noticed by a large proportion of patients. Some cases feel no premonitory pain. Some may be giving a history of an ordinary attack of conjunctivitis not in any way connected with the subsequent marginal degeneration. Others may owe their symptoms to a low-grade astigmatism arising in the early stages of the disease, and interfering with binocular vision. Nevertheless, there seems to be a group of patients who give a very definite history of pain coming on for no apparent reason; an intermittent pain that altogether disappeared before any visual symptoms arose. If the disease really is a degeneration, as most of the evidence indicates, then these attacks of pain might well be due to irritation from the products of histolysis when the corneal stroma begins to suffer destruction. After a time, some form of immunity to the histolytic substances is acquired, and the pain ceases.

Sir John Parsons has kindly given me permission to report a case of marginal degeneration in a patient under his care at Moorfields Eye Hospital. The patient is a schoolmaster, now aged 44 years, who first attended Moorfields in 1907, suffering from conjunctivitis. The inflammation affected chiefly the lower palpebral portion of each conjunctiva, and was not very severe. At that time he had in each eye 0.5.D. of astigmatism, correction of which gave $6 / 6$ vision. In 1916, at the age of 30 , he returned on account of recent attacks of pain in the left eye. This pain was always worse in the mornings, and nothing relieved it. A vascularised peripheral gutter was noticed in the upper portion of the left cornea. With the old correction, vision of 6/9 was obtained. At the end of 1920 , he complained that the sight of the left eye had been failing for one month. Left vision was now 6/12 with the aid of his 1909 glass; right vision unaltered. In 1925, left vision had fallen to $6 / 36$, and in 1928 to $6 / 60$ with the old correction. When he again attended Moorfields this year, the left vision was reduced to fingercounting, with or without his glass. He now complained of pain in the right eye like the pain he felt in the left eye in 1916. Refraction yields these results : R.V, $\bar{c}-0.5 \mathrm{D}$. cyl., $\Downarrow 105^{\circ}=6 / 6$; L.V. $\bar{c}+2 \cdot 0$ D. sph. and $-12 \cdot 0$ D. cyl., $\downarrow 90^{\circ}=6 / 12$ mostly. On 
naked-eye inspection, the right eye appears normal ; the left eye, as depicted in Figure 1, shows a crescentic vascularised ectasia situated at the upper portion of the periphery, and measuring about $3 \mathrm{~mm}$. across the widest part. Centrally the ectasia is bounded by a distinct wavy white line, at which the vessels stop short.

Figure 2, a slit-lamp section of the left cornea in the neighbourhood of the ectasia, demonstrates the protrusion of the cornea, which is here only one-quarter of its normal thickness. On slitlamp examination, endothelium is not visible in the middle, but its amorphous remains appear in the lateral portions of the ectatic zone.

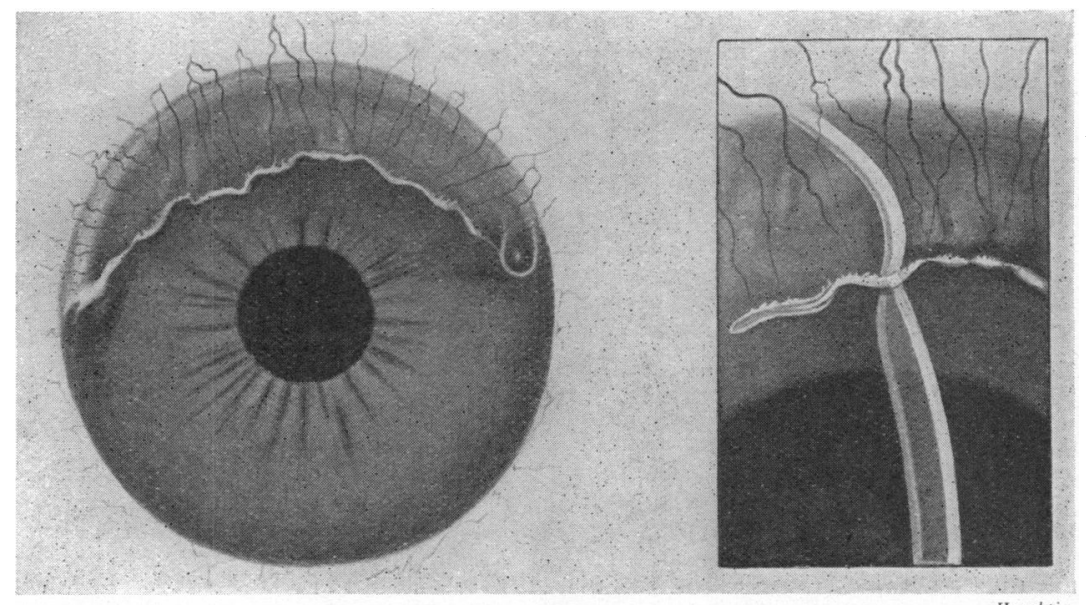

Fig. 1.

FIG. 2

Immediately below the two ends of the white line, the corneal stroma for a distance of $1 \mathrm{~mm}$. shows abundant small, glistening crystals, and ill-defined greyish opacities. At the lower limbus, in the region 7 to 5 o'clock, there is an abnormal accentuation of the scleral prongs that compose the palisade zone; an encroachment here and there of conjunctival vessels on the cornea for a distance of $1 \mathrm{~mm}$.; a number of scattered greyish dots of opacity in the substantia propria; but as yet no demonstrable thinning of the cornea. These phenomena presumably denote the beginning of that process whose later stages are evident in the upper periphery. In the right cornea, which appeared normal to naked-eye inspection, the slit-lamp revealed, at the 10 to 2 o'clock and the 7 to 5 o'clock regions of its periphery, the same early changes without any appreciable thinning. A furrow will almost certainly appear on the right cornea at some future time.

This clinical entity has been given various names; e.g., furrow keratitis, marginal ectasia, and marginal degeneration of the 
cornea. The last of these three is manifestly the most descriptive, because furrowing and ectasia, although inevitable, are merely landmarks in the progress of the degeneration.

\section{LITERATURE.}

Adamantiadis.-Arch. d'Ophtal., Vol. XXX, p. 46, 1910.

Arlt.-Lehrbuch der Augenheilk. (quoted by Seefelder), 1881.

Axenfeld.-Klin. Monatsbl. f. Augenheilk, Vol. XLV, ii, p. 578, 1907.

Cattaneo.-Ann. di Ottal., Vol. LIV, p. 1291, 1926.

Coats.-Trans. Ophthal. Soc. U.K., Vol. XXXI, p. 5, 1911.

Denti.-Boll. d'Ocul., Vol. IV, 1925.

Drüner and Wiedersheim.-Klin. Monatsbl. f. Augenheilk., Vol. LXXII i, p. 509, 1924.

Fisher.-Trans. Ophthal. Soc. U.K., Vol. XXX, p. 25, 1910.

Fleischer.-Klin. Monatsbl. f. Augenheilk., Vol. XLVI, ii, p. 90, 1908.

Frank - Dissertation, Marburg, 1896.

Früchte.-Klin. Monatsbl. f. Augenheilk., Vol. XLV, ii, p. 66, 1907.

Fuchs, E.-Arch.f. Ophthal., Vol. LII, ii, p. 317, 1901.

Ibid., Vol. LXXXIX, p. 386, 1915.

Gifford.-Amer. Jl. of Ophthal., Vol. VIII, p. 16, 1925

Gilbert.-Klin. Monatsbl. $f$. Augenheilk., Vol. XLVI, ii, p. 145, 1908.

Gonzalez.-Amer. Jl. of Ophthal., Vol. VII, p. 452, 1924.

Handmann.-Klin. Monatsbl. f. Augenheilk., Vol. XLVI, ii, p. 264, 1908.

Ischreyt.-Klin. Monatsbl. f. Augenheilk., Vol. XLV, i, p. 197, 1907.

Junius.-Zeitschr. $f$. Augenheilk., Vol. XXVIII, p. 43, 1912.

Knapp.-Arch. of Ophthal., Vol. XXXVII, p. 341, 1908.

Koby.-Rev. Gen. d'Ophtal., Vol. XXXVII, p. 245, 1923.

Komoto.-Klin. Monatsbl.f. Augenheilk., Vol. XLVII, ii, p. 447, 1909.

Kyrieleis.-Klin. Monatsbl.f. Augenheilk, Vol. LXVI, i, p. 754, 1921.

Lauber.-Klin. Monatsbl. $f$. Augenheilk., Vol. XLIII, i, p. 382, 1905. Zeitschr. f. Augenheilk., Vol. XXII, p. 78, 1909.

Lauterstein.-Klin. Monatsbl. f. Augenheilk., Vol. LXVI, i, p. 529, 1921.

Markus.-Trans. Ophthal. Soc. U.K., Vol XXXI, p. 1, 1911.

Marquez.-Espana Oftal., Vol. IV, p. 112, 1916.

Molodenkowa.-Klin. Monatsbl. f. Augenheilk., Vol. XLVII, ii, p. 778, 1909.

Passera.-Giorn. di med. milit., Vol. IV, 1911.

Passera e Vandetti.-Ophthalmologica, i, p. 96, 1909.

Pesme.-Arch. d'Ophtal., Vol. XL, p. 297, 1923.

Rochon-Duvigneaud et Ducamp.-La Clin. Ophtal., Vol. XIX, p. 469, 1913.

Rschanlzyn.-Klin. Monatsbl. f. Augenheilk., Vol XLVI, i, p. 433, 1908.

Rubbrecht.-Arch.d'Ophtal., Vol. XXXIX, p. 174, 1922.

Rupprecht.-Klin. Monatsbl. f. Augenheilk., Vol. XLV, i, p. 34, 1907.

Schmidt-Rimpler.-Augenheilk. und Ophthal., p. 486, 1889.

Schutz.-Arch. of Ophthal., Vol. XL, p. 368, 1911.

Seefelder.-Klin. Monatsbl.f. Augenheilk., Vol. XLIV, i, p. 61, 1906.

Ibid., Vol. XLV, i, p. 475, 1907.

Ibid., Vol XLV, ii, p. 573, 1907.

Ibid., Vol. XLVIII, i, p. 321, 1910.

Stella.-Boll. d'Ocul, Vol. III, 1924.

Terrien.-Arch.d'Ophtal., Vol. XX, p. 12, 1900. Ibid., Vol. XXXVIII, p. 523, 1921.

Trantas.-Gaz. Med. d'Orient., p. 233, 1912. La Clin. Ophtal., Vol. XXIX, p. 621,1925

Uhthoff.-Klin. Monatsbl. f. Augenheilk., Vol. LXVIII, i, p. 289, 1922.

Uicker.-Dissertation, Freiburg, 1906.

Van Duyse.-Arch. d'Ophtal., Vol. XXX, p. 657, 1910.

Vavouline.-Arch. d'Ophtal., Vol. XXXV, p. 125, 1916.

Wischnjakow.-West. Ophthal., Vol. XXVI, 1909

Zentmayer..-Ann. of Ophthal., Vol. XX, p. 90, 1911. 